TECHNICAL TRANSACTIONS 3/2018

CZASOPISMO TECHNICZNE 3/2018

MECHANICS

DOI: $10.4467 / 2353737$ XCT.18.049.8344 SUBMISSION OF THE FINAL VERSION: 19/2/2018

\author{
Andrzej Skrzyniowski \\ Andrzej Mruk (jendrek@mech.pk.edu.pl) \\ Faculty of Mechanical Engineering, Cracow University of Technology \\ Dorota Skrzyniowska (skdorota@pk.edu.pl) \\ Faculty of Environmental Engineering, Cracow University of Technology
}

\title{
ROTARY SMART CAR PARKING SYSTEM
}

\section{SAMOCHODOWY PARKING OBROTOWY}

\begin{abstract}
Problems with parking individual cars, particularly in urban areas, were already experienced by the inhabitants of developed countries in the interwar period. These problems continue to appear, as the number of cars increases and there are fewer and fewer parking spaces. Therefore, solutions are sought after to ensure the largest possible number of parking spaces with the smallest occupied area, especially in large agglomerations of highly developed countries. The article presents one of the possible solutions - rotary car parks (The Rotary Automated Car Parking System; RACPS). The research results reffered to in the article are the effect of works conducted at the Faculty of Mechanical Engineering of the Cracow University of Technology in the field of modelling and optimisation of a rotary car park $[5,6,8]$.
\end{abstract}

Keywords: rotary parking system, smart parking system, parking spot, Taguchi method, typology of parking lots, reducing model of rotary parking lots, RACPS, parking system solutions

\section{Streszczenie}

Kłopoty z parkowaniem samochodów indywidualnych szczególnie w obszarach miejskich mieli już w okresie międzywojennym mieszkańcy krajach rozwiniętych. I te problemy w dalszym ciągu się pojawiają, ponieważ ilość samochodów wzrasta, a miejsc do parkowania mamy coraz mniej. Dlatego poszukuje się rozwiązań, które mają zapewnić jak największą liczbę stanowisk parkingowych przy jak najmniejszej powierzchni zajmowanej, szczególnie w wielkich aglomeracjach krajów wysokorozwiniętych. W artykule przedstawiono jedno z możliwych rozwiązań, jakim są parkingi obrotowe (The Rotary Automated Car Parking System; RACPS). Wyniki badań przytoczone w artykule są efektem prowadzonych na Wydziale Mechanicznym Politechnice Krakowskiej prac z zakresu modelowania i optymalizacji obrotowego parkingu samochodowego $[5,6,8]$.

Słowa kluczowe: obrotowy parking samochodowy, miejsca parkingowe, optymalny parking obrotowy, metoda Taguchi, typologia parkingów samochodowych, model redukcyjny parkingu obrotowego 


\section{Introduction}

The first multi-level automated car park (APS) was built in Paris in 1905 at Ponthieu Street, located near Champs Elysées, with an elevator that transports cars to the appropriate level, where the staff parked their cars. Automated car parks appeared in the USA (New York) in the 1920s and remained popular there until today [24].

The most famous car parks of this type in Europe are the so-called car towers. An example is a car park in the Volkswagen plant in Wolfsburg, Germany, which was built from two concrete silos originally used for storing grain, creating the TurmFahrt glass towers - car parks intended for cars leaving the production line. Each can accommodate 400 cars. On their way to the silo, they go through an underground tunnel connecting the factory and the towers. Both silos can also be visited. Visitors sit in a glass gondola, i.e. an elevator, moving up and down through the centre of each building. The view of tens of cars appearing as if they were hanging in the air is on of the town's major attractions.

Currently, the largest automated car park in Europe is a car park for 1000 cars located in Denmark in Århus (DOKK1) at Hack Kampmanns Plads 6 [25].

\section{Typology, a brief review of car park solutions and justification for choosing a rotary car park for analysis}

Rotary car parks are one of the most advanced systems among all parking systems used so far [23].

For the purposes of the analysis, the following types of car parks have been considered:

PA - automatic car park (generally),

PP - automatic car park with inter-storey progressive movement of cars,

PO - automatic car park with inter-storey rotary movement of cars (rotary car park),

PTW - traditional multi-level car park, which is a closed construction facility only,

OPO - optimal rotary car park, as the preferred technical development.

The selection of OPO car parks for the above purposes (for the model: PO 10, i.e. 10 cars as the smallest for this type of unit) is justified by the following features resulting especially from a parametric comparison with the car park types listed above:

1) possibility of modular coaxial increase of parking capacity (including up to 120 and more, allowing comparative operations) owing to the adopted car entry/exit direction perpendicular to the drum axis,

2) no exhaust emissions to the environment, which, according to the calculation results, makes both OPO and all PA car parks "an ecological profit" in relation to the PTW car park,

3) approx. 50\% energy saving in relation to the PP car park used most often due to the lower resistance in the drum rotational movement than in the platform progressive movements, which allows for approx. a twofold decrease of installed power, 
4) approx. 60\% shorter car access time compared to PP car park (90 instead of 230 seconds) due to shorter internal transport routes and a larger number of entry and exit stations,

5) building coverage ratio of $2.8 \mathrm{~m}^{2} /$ number of parking spaces representing approx. $22 \%$ and approx. $86 \%$ space savings in relation to PP and PTW car parks,

6) building capacity ratio of $48 \mathrm{~m}^{3} /$ number of parking spaces representing approx. $17 \%$ and approx. $47 \%$ space savings in relation to PP and PTW car parks,

7) unit investment cost of PLN 30 thousand/number of parking spaces representing approx. $60 \%$ and approx. $75 \%$ savings in expenditures concerning serial production in relation to PP and PTW car parks,

8) adoption of the following design solutions, which are advantages over other car parks listed:

- levelling platforms with the use of two prismatic guides with the shape of a circular sector, which gives the entire openwork structure the appropriate lightness and the possibility of proper support of the drum on its both sides,

- transfer of the drive on the drum side perimeter instead of on the axis with the use of a finger cycloidal chain gear, which, in addition to the dimensional minimisation of the drum bearing shafts, enables full self-locking of its movement,

- lowered trench depth to approx. $1 / 3$ of the ground height, i.e. to the parameter conditioning rational adoption of the non-returnable automatic direction (because of gravity) of parking and unparking (entry from one side and exit from the other side of the drum),

- method of car entry and exit eliminating access roads and ways, thus eliminating land and space losses,

- modular multiplication of the car park size, reducing the effects of possible system failures (then, one failure affects only one module).

\section{Description of a rotary car park}

The technical solution of a multi-level, automatic car park presented below is substantially ahead of the existing solutions and responds to the problems presented in the literature on car parks. Therefore, it [5]:

- lowers the investment cost of a parking space several times;

- reduces the value of its total area indicator;

- reduces the average time of parking and unparking vehicles;

- significantly increases the reliability of its operation

- reduces the amount of operating costs of the car park.

The suggested car park (Fig. 1) is a car park rotating around its horizontal axis. The car goes directly to the parking space; therefore, no internal access roads or ways are needed. This car park has no ceilings, load-bearing walls or pillars, and the gravitational system of moving vehicles (using the inclination of the transit area) does not require any mechanical devices or drives. It is simple, cheap and reliable $[8,26]$. 
Depending on the car park size, the aforementioned platforms, together with hangers, rotatably mounted in the rotary drum sides, may be single or several-level, with two cars on each level. The size of the drum is also determined by the number of arms with platform hangers [8].

The drum, mounted on two supports, rotates, and the entry and exit of cars takes place near half of its height, in a plane perpendicular to its axis of rotation. Therefore, the car park is partly let into the ground, and partly protrudes above it [8].

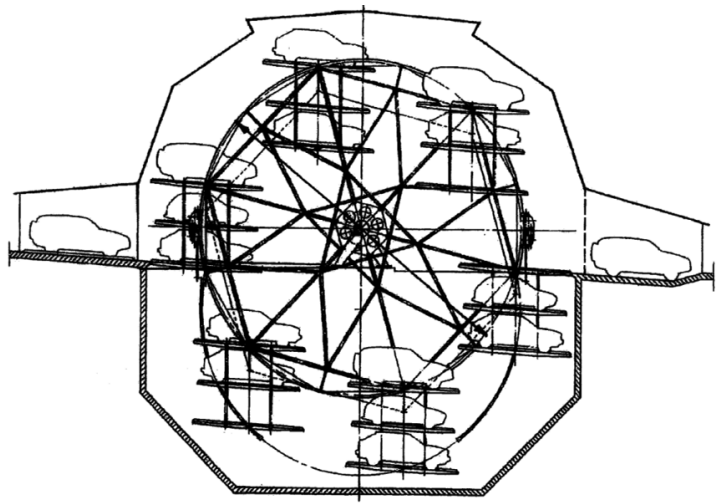

Fig. 1. Rotary car park - an example of a solution [26]

To verification of working proposed parking physical design in the scale of 1:33 (Fig. 2-5) was performed.

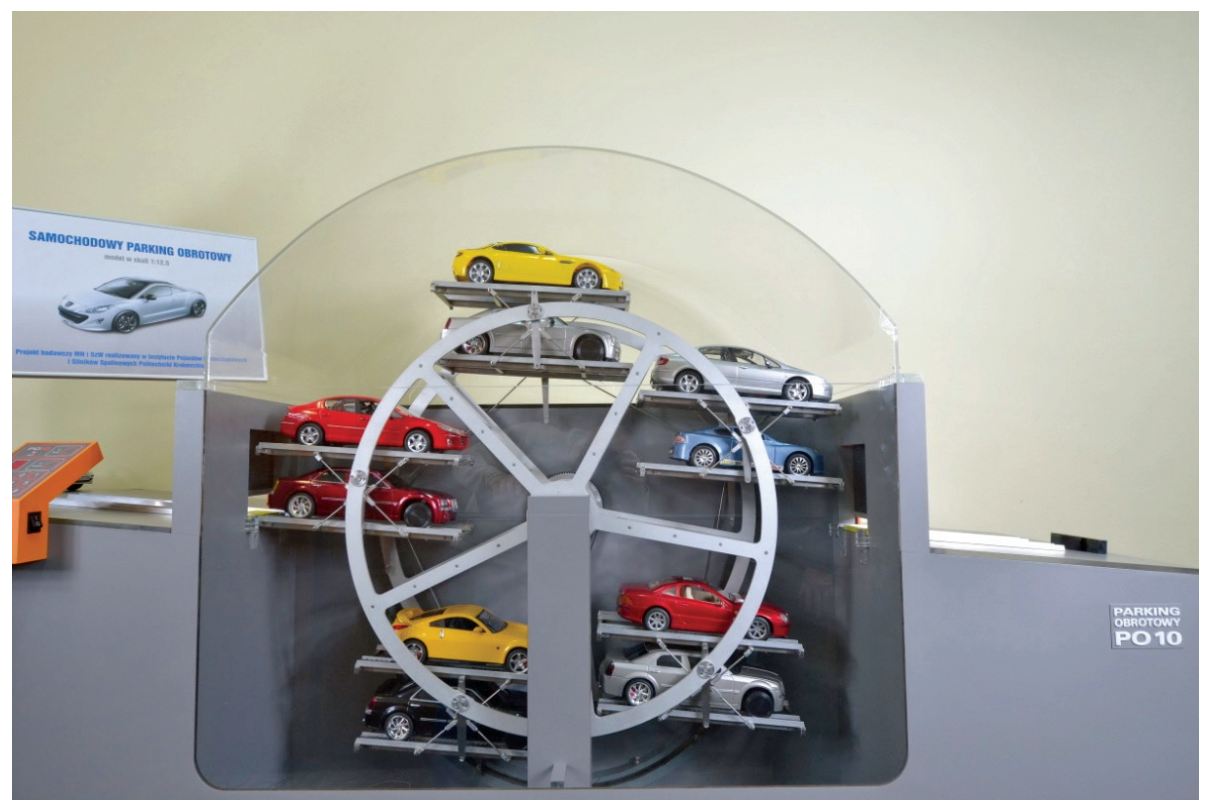

Fig. 2. Rotary car park - model, side view 


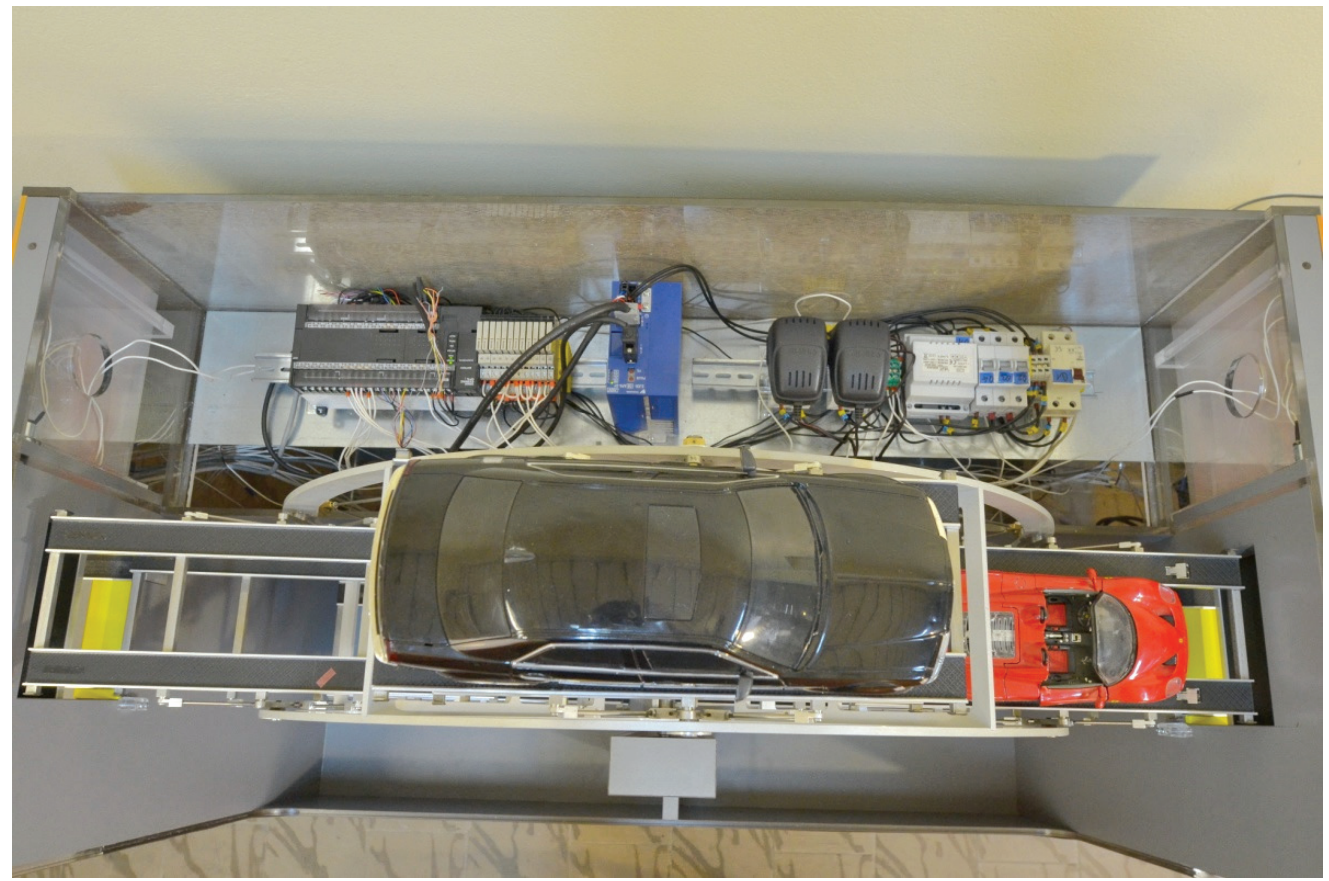

Fig. 3. Rotary car park - model, overhead view

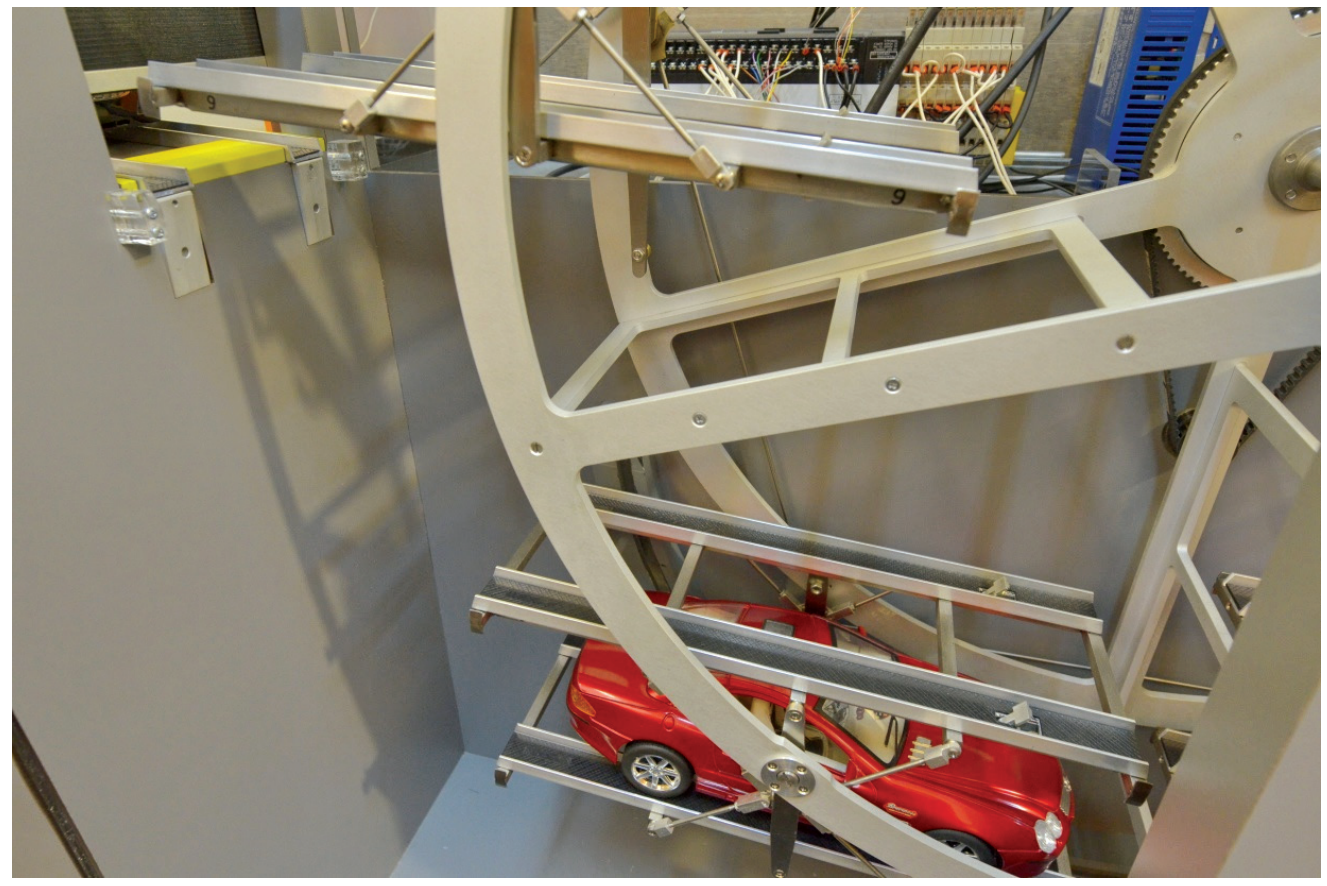

Fig. 4. Rotary car park - model, car view on the platform 


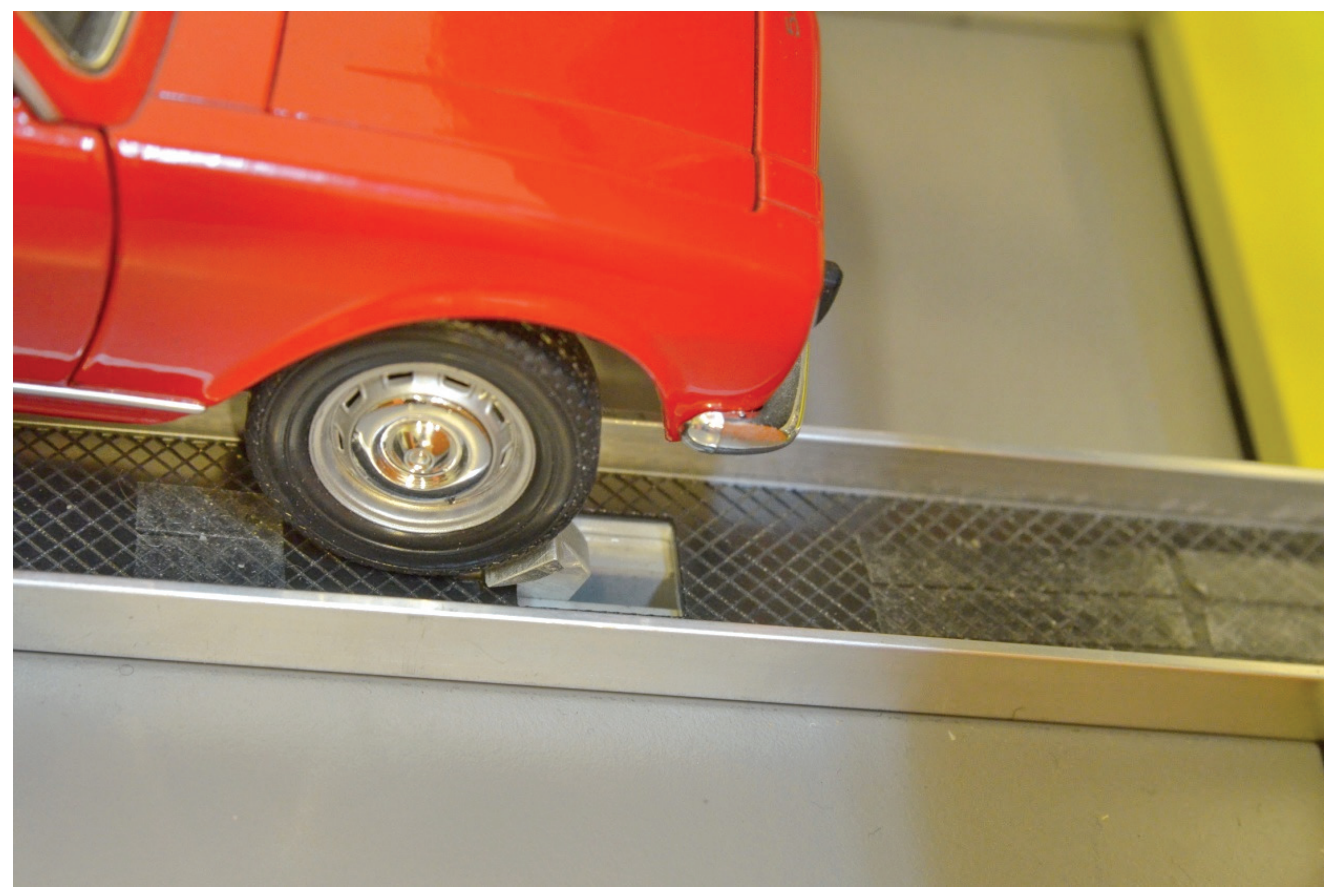

Fig. 5. Rotary car park - model, platform view

The operation of the model was navigated by a complied computer program. The carried-out study on the model allowed for dates to be accepted for the optimisation of the parking solution.

\section{Design of a rotary car park model - computer simulation}

The model design of the car park was conducted in two parts: control automation and automation of the mechanical part.

For the automation of the car park operation, entry - parking - exit of cars, the control diagram is adopted and modelled in Fig. 6.

To perform the automation tasks, a controller was selected, for example, for the task being developed: Omron sensor type CJ1, which gives the possibility of 2560 digital input and output signals, which in the case of the "extensive" car park model will allow to expand the controller capabilities.

The Omron-CX-Programmer V4.0 software package was used to write the programme to the controller.

CX-Programmer has all the tools for creating programmes in the ladder language.

The programme was divided into sections, which facilitated programming and made "movement" in the written programme easier.

Each section is responsible for individual elements of the car park movement control in accordance with the following list: 


$\begin{array}{ll}\text { Section 1 } & \text { Entry to platform 1 } \\ \text { Section 2 } & \text { Entry to platform 2 } \\ \text { Section 3 } & \text { Exit from platform 1 } \\ \text { Section 4 } & \text { Exit from platform 2 } \\ \text { Section 5 } & \text { Initial conditions } \\ \text { Section 6 } & \text { Main programme } \\ \text { Section 7 } & \text { Subprogramme calls } \\ \text { Section } 8 & \text { Verification if there's a free space in the car park } \\ \text { Section 9 } & \text { Calculation of weights } \\ \text { Section 10 } & \text { Selecting a position on platform 1 } \\ \text { Section 11 } & \text { Selecting a position on platform 2 } \\ \text { Section 12 } & \text { Calculation of the car park rotation angle at the entry } \\ \text { Section 13 } & \text { Car park rotation implementation } \\ \text { Section 14 } & \text { Start of counting car parking time } \\ \text { Section 15 } & \text { Selection of the entry position } \\ \text { Section 16 } & \text { Calculation of the car park rotation angle at the exit } \\ \text { Section 17 } & \text { Car park rotation implementation } \\ \text { Section 18 } & \text { End of counting car parking time [5]. }\end{array}$

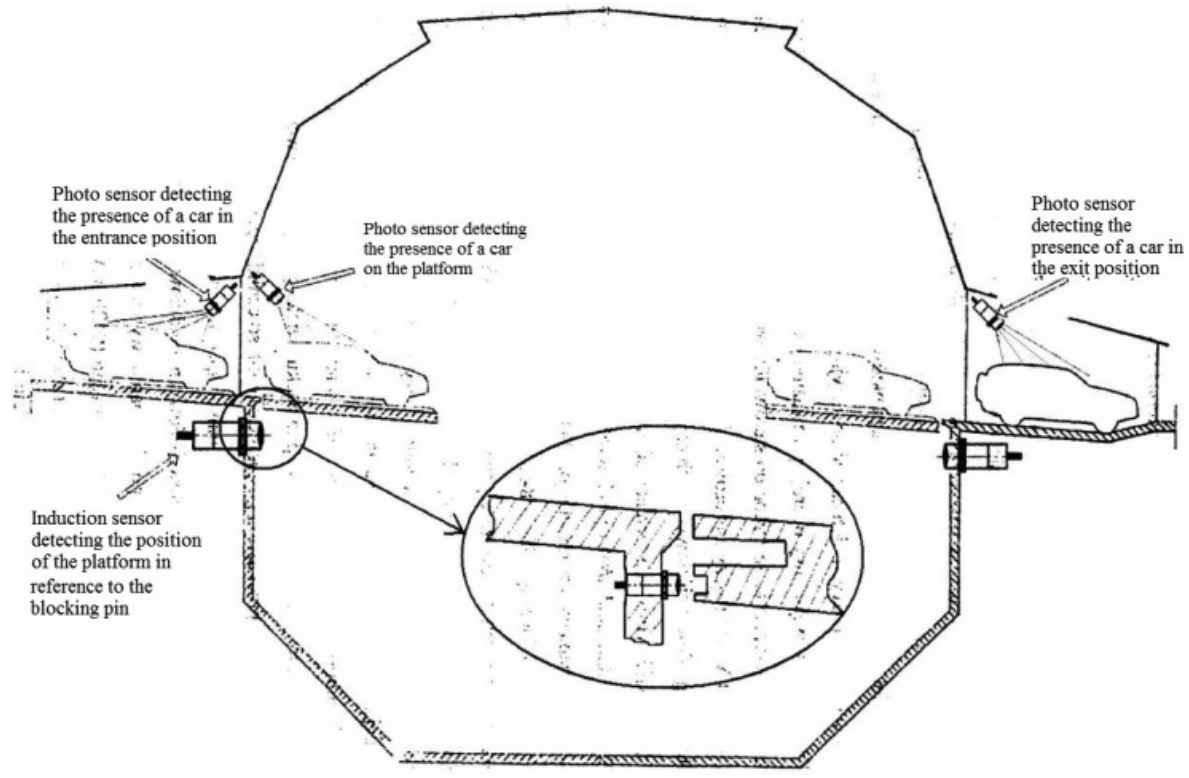

Fig. 6. Diagram of the arrangement of sensors for automatic control: entry - exit of a car [22]

\section{Description of the optimisation programme}

Pieces of the programme controlling operation of the car park responsible for searching for the optimal solution for the operation parameters: cost, road and efficiency, were presented in the development of the report on the research project [5]. 
The work covers an algorithm for determining "entry" and "exit" positions, subprogrammes checking the status of free spaces, subprogramme assigning " 0 " or " 1 " to each platform, " 0 " when there is no car on the platform and " 1 " when the platform is occupied, subprogramme counting " 1 ". Knowing the number of cars and the distance of the platforms from the centre of the car park, the coordinates of the centre of gravity $x_{c c} y_{c c}$ are calculated.

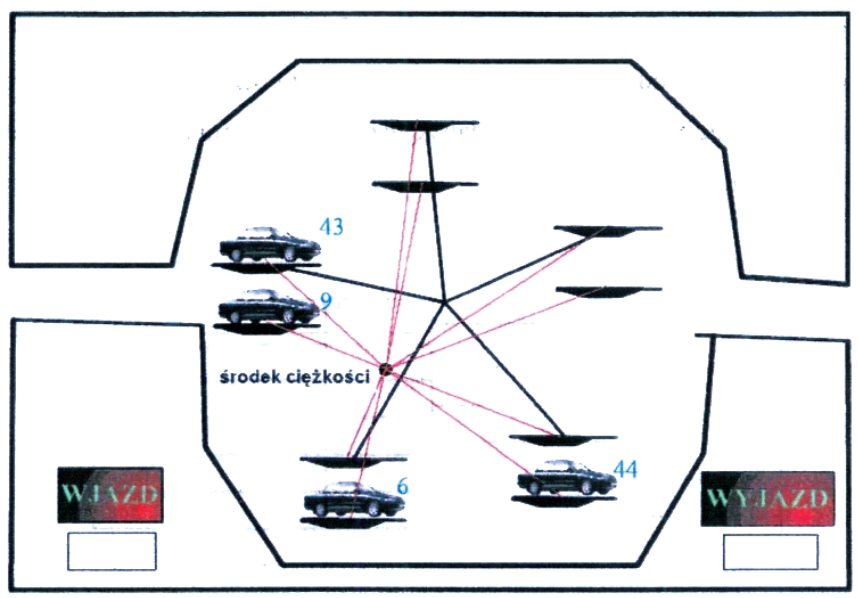

Fig. 7. Calculation of the centre of gravity

On this basis, in the next subprogramme, calculations are made to determine the length of sections from the centre of gravity to each of the individual platforms.

On the basis of these section lengths, the weight significance of each platform is determined later in the programme.

After calculating the length of the sections connecting the centre of gravity with each of the platforms, the programme sorts them in order from the largest to the smallest and assigns significance to each where 1 corresponds to the platform that is the nearest to the centre of gravity, while 10 to the platform the most distant to the centre of gravity. The next subprogramme assigns significance of the position, which informs about the distance (rotation angle) from the entry to all platforms, while the largest number represents the smallest angle and vice versa.

Therefore, the entry of the next car on an empty platform is determined by the subprogramme that calculates the ratio of the significance of the entry and the significance of the length of the section from the centre of gravity (gravity significance). Therefore, every next entering car will be parked in the position with the highest significance.

In this way, the number of the platform to which the car should enter is determined so that the centre of gravity is close to the centre of the car park.

\section{The algorithm of rotary car park operation}

A detailed description of the car park operation during entry and exit is presented in [5]. Below, there are only its most important elements. 


\section{The algorithm of rotary car park operation during entry}

After reading the bar code from the identifier, it is checked whether there are free spaces in the car park. If so, the entry gate (bram1_gor) is opened and, at the same time, the wheel rotation causes the provision of the appropriate platform to the "entry" position.

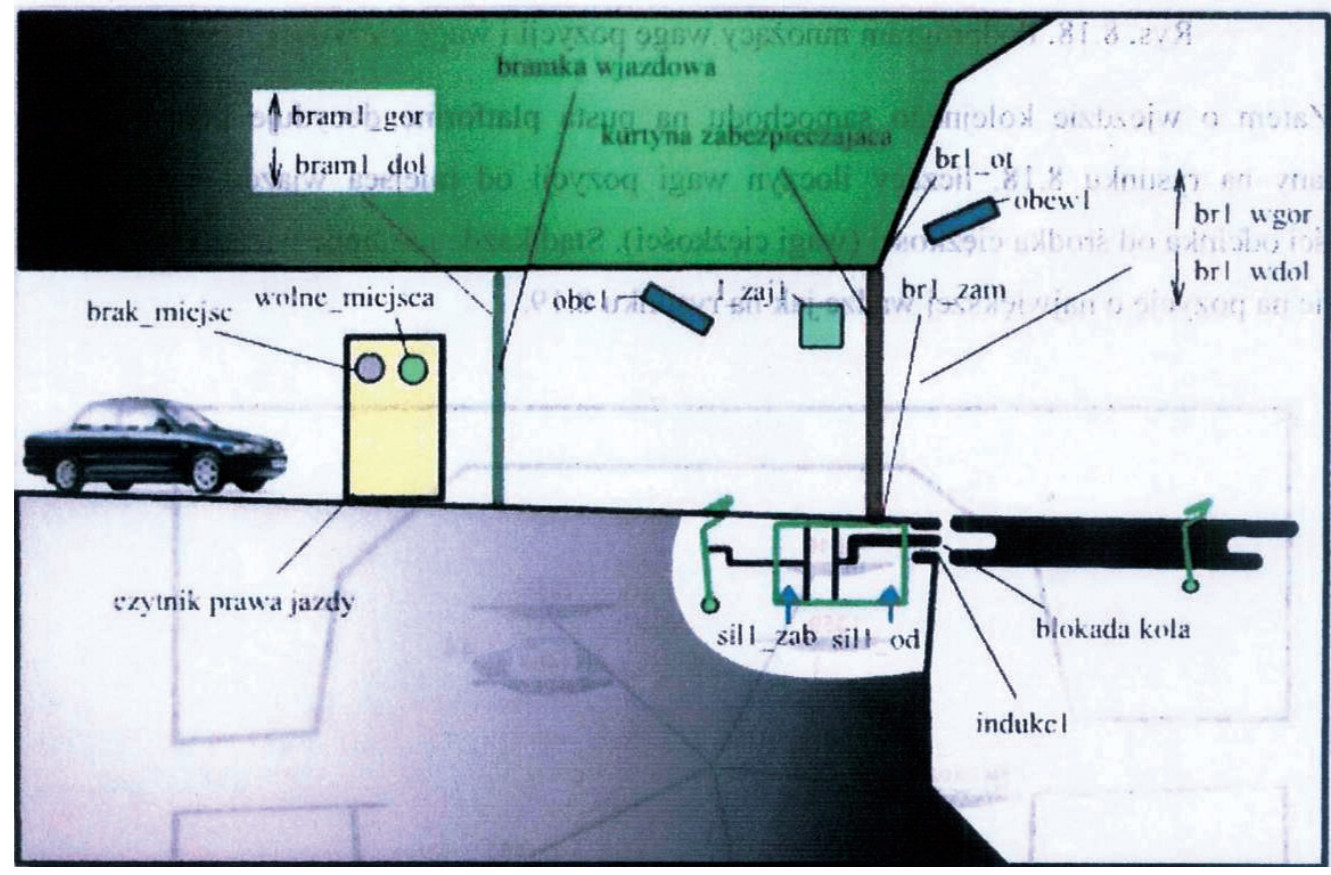

Fig. 8. Arrangement of entries and exits in the entry part [5]

After stopping the car behind the entry gate, the presence sensor (obe1) detects its presence. The driver re-inserts the identifier to the reader informing that he got out of the car. Then, the entry gate closes (bram1_dol). After, using an inductive sensor (indukc1), it is checked whether the wheel has stopped and the presence sensor (obew1) checks whether the place behind the curtain is free.

If both of these conditions are met, the security curtain (br1_wgor) is opened, the wheel is locked with a locking pin (sil__zab) and the car is automatically shifted onto the provided platform. After the car has been detected by the presence sensor inside the car park (obew1) and waiting for two seconds, the security curtain (brl_wdol) closes and the wheel lock is released (sil1_od). The car is parked.

\section{The algorithm of car park operation during exit}

After reading the bar code from the identifier, it is checked whether the car is in the car park. If so, the car park is rotated, and an appropriate platform is set for the "entry" position. Then, using an inductive sensor (indukc3), it is checked whether the wheel has stopped and the presence sensor (obe3) checks whether the place in front of the curtain is free. If both of 
these conditions are met, the security curtain (br3_wgor) is opened, the wheel is locked with the locking pin (sil3_zab) and the car is automatically shifted in front of the exit gate.

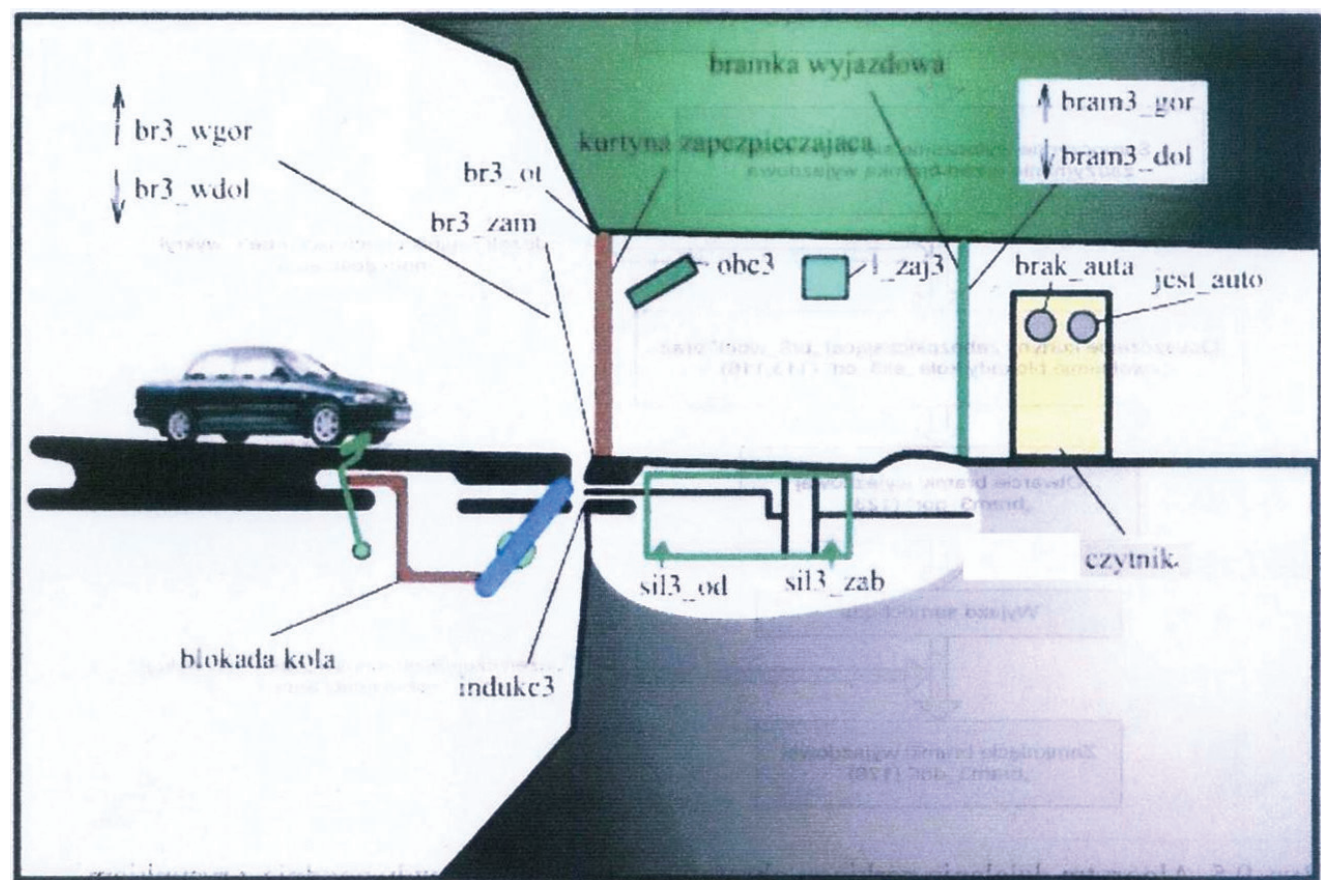

Fig. 9. Arrangement of entries and exits in the exit part [5]

After the car has been detected by the presence sensor (obe3) and waiting for two seconds, the security curtain (br3_wdol) closes and the wheel lock is released (sil3_od). Five seconds after the car is detected by the presence sensor (obe3), the exit gate opens (bram3_gor) and the driver drives away. After driving away, the exit gate closes (bram3_dol).

The process visualisation system has been made with the use of the InTouch 8.0 programme. InTouch consists of three main programmes: Application Manager, WindowMaker and WindowViever programmes[15].

The creation of a visualisation (simulating) window for the designed process was conducted using both ready-made templates (wizards) and special graphic objects drawn for this purpose, due to their lack in the programme libraries.

The screen window presents the "circle" of the car park with platforms and cars rotating with them. After entering a car on a platform, its identification number will appear along with it, which, like a car, is moving in a rotational movement and is inseparably attached to it until the car has left.

The analysis of the conducted simulation tests showed the correctness of the adopted optimisation methods. Simulation of the programme written in the InTouch environment for the adopted parameters of the rotary car park gave positive results. For several dozens of tests, the simulation of the "entry and exit" of cars into the car park did not show any errors. The 
tests concerned only the rotation of the drum (car park circle) and torque optimisation. The correctness of the selection and operation of the entire programme for individual mechanisms was checked in real conditions on the car park prototype [5].

In Fig. 10-12, examples of screen views (graphic windows) designed to visualise the operation of a rotary car park are presented.

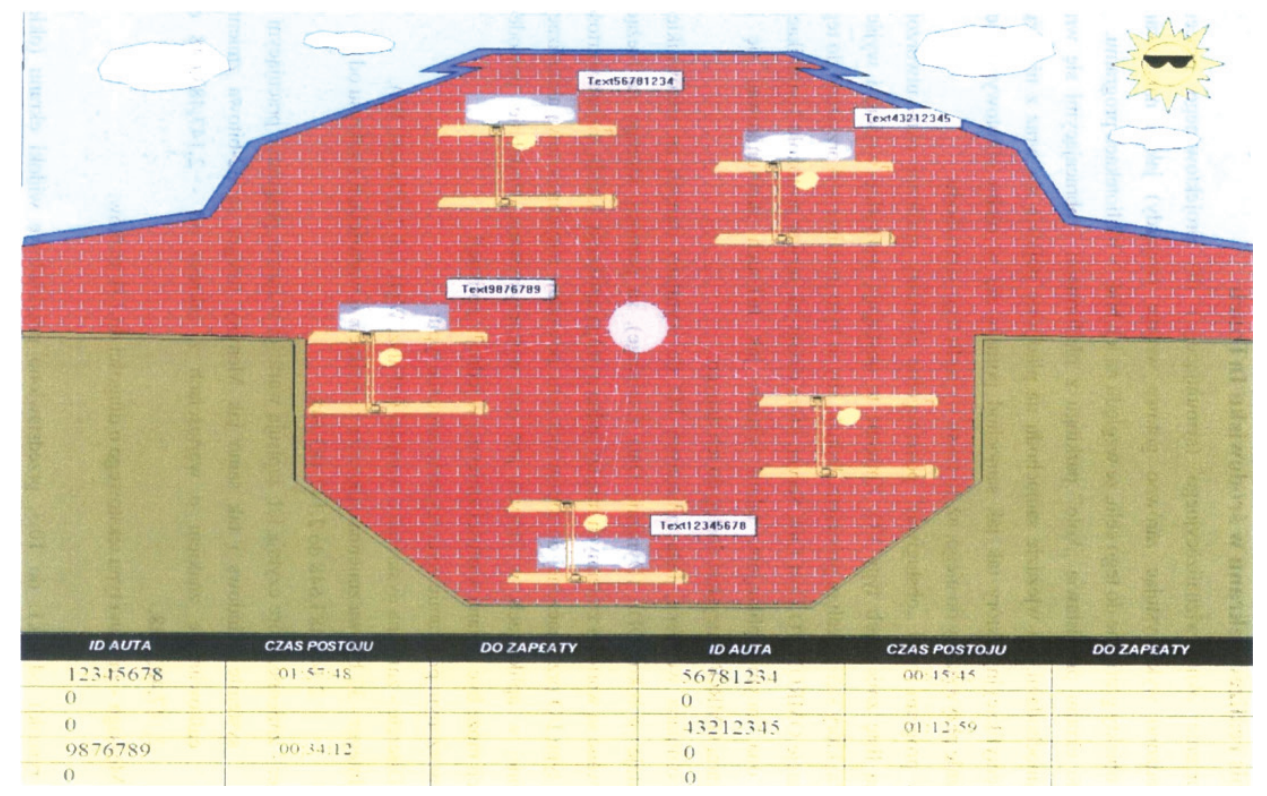

Fig. 10. Screen presenting the circle of the car park with platforms and cars placed on them [5]

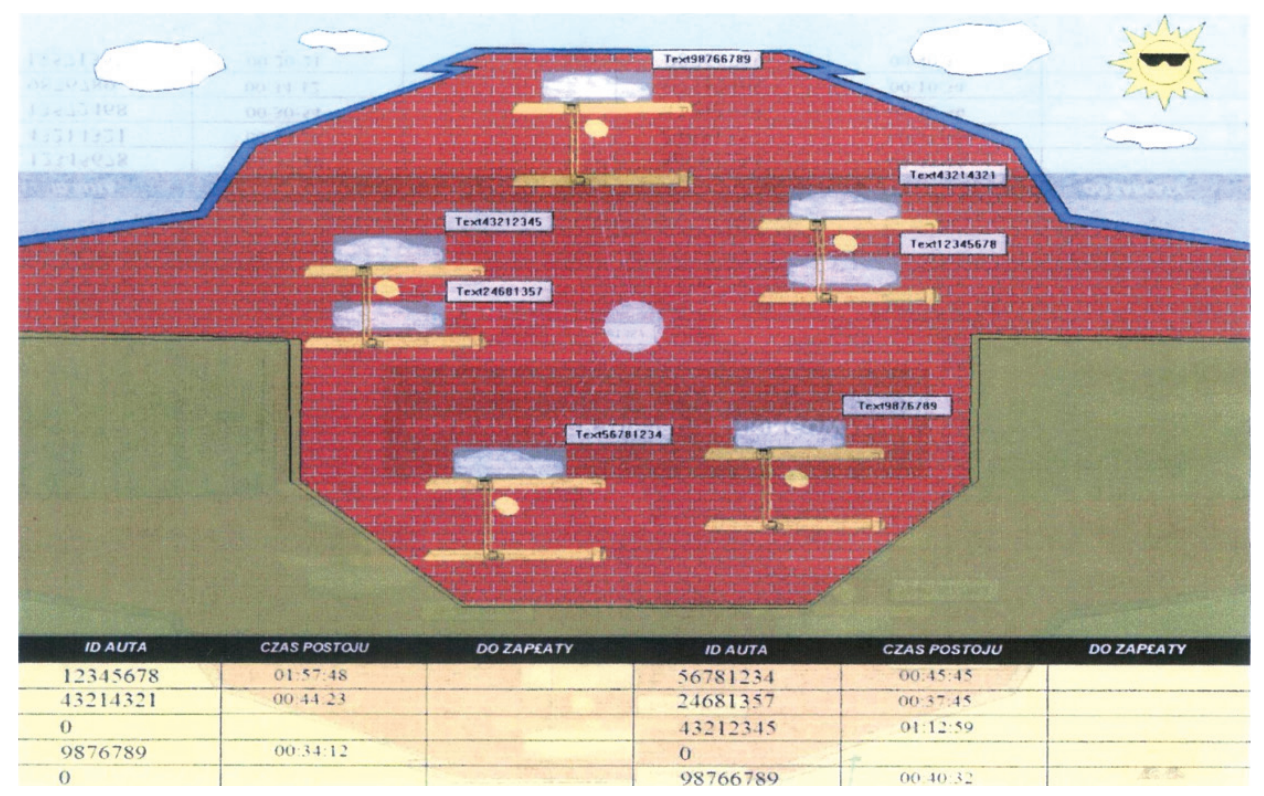

Fig. 11. Screen presenting the moment after the entry of other cars [5] 


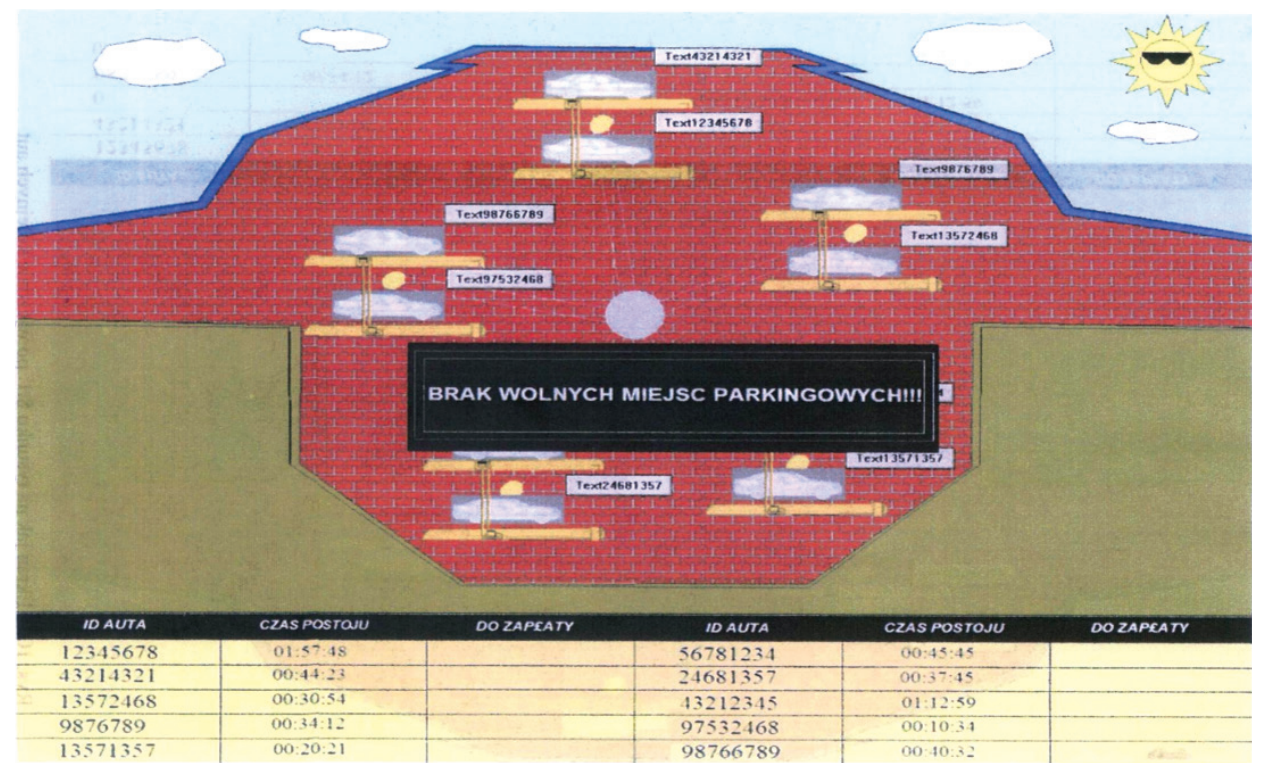

Fig. 12. Screen presenting the "alarm" message informing about the lack of free parking spaces [5]

\section{Structural development of the car park model and detailed development of the selected units}

The PO - 10 rotary car park model was designed as a reduction model at scale of $1 \div 12.5$ (due to the availability of car models in this size scale). The model's construction was preceded by computer tests of the nominal model as well as structural and operational analyses.

As a result of these works, the design of the model was created.

The model consists of three basic units: a mobile part with car parking platforms, an electronic part: a drum drive with rotational speed control, an electronic part allowing automatic entry to a parking space and exit after parking. The original, characteristic way of entry and exit from a parking space is the gravitational movement forced by the inclination of entry and exit channels, which constitute the parking space.

For utility reasons, individual parts of the model were made of various materials. Mechanical parts were made of metals; other parts were made of plastics with high resistance to impact and abrasion. The model is controlled by means of an electronic, ergonomically designed panel.

The functional and kinematic structure consists of entrance blockades, entry doors, a rotary drum with a unit of five "gondolas" with two platforms in each, that is, ten in total, exit blockades on platforms and exit doors. The drive structure of the model consists of four systems: drive of the entry blockades, drive of entry and exit doors, drive of a rotary drum and drive of platform exit blockades.

The main drive of the model was executed with an OMRON servo motor with a torque of $2.7 \mathrm{Nm}$ and a maximum rotational speed of $2000 \mathrm{rpm}$. The motor has a built-in encoder with 
a resolution of 10,000 pulses/rotation. It is possible to set the position with a resolution of up to $1 / 50,000$ of rotation with the "lowering" belt transmission.

After switching on the power supply, the drum with "gondolas" can be positioned in relation to the limit switch built near the entry base position of the zero "gondola". In relation to entry and exit, the remaining "gondolas" are based in relation to this base position.

The locks of the right and left wheels in the entry and also in the exit are set by means of DC motors with transmissions. The lock operation is controlled by testing contacts of the limit switches indicating the status of locking and releasing.

The PLC exercises supervision over the model operation. The model is operated by a human via a control panel with a plastic keyboard.

The external appearance of the model was created as the last component of the whole. It is the result of the proper display of the construction and mechanical as well as an electric and electronic unit.

It consists of a base, a full back wall, a partially glazed front wall, a rounded glazed top cover adapted to the drum shape, entry ramp, exit ramp, visible inner walls and invisible reinforcements.

The model walls are made of $8 \mathrm{~mm}$ thick metaplex. The visible parts are covered with HPL plastic, epoxy resin $1 \mathrm{~mm}$ thick in RAL 7037 colour. This material is highly resistant to mechanical shock and abrasion as well as chemically resistant. The "glazed" front wall and "shade" are made of a $4 \mathrm{~mm}$ colourless metaplex. If necessary, both parts are easily removable. Lids are similarly removable above the entry and exit ramps, and above the chamber at the back of the model holding drives and electronics. This gives convenient access to mechanisms intentionally hidden to achieve an aesthetic effect of the entire model.

Dimensions of the model with the base are; length $-2040 \mathrm{~mm}$, width $-600 \mathrm{~mm}$, height with base $-1600 \mathrm{~mm}+$ feet, the model itself $-1200 \mathrm{~mm}$.

Tests of gravitational traffic of cars at the entry and exit of the car from the parking space have been conducted.

The "model" test showed sufficient inclination of the channels at the entry and exit $2^{\circ}$. It is an inclination at the same time ensuring stopping the car before and after entering the platform in the parking space.

Tests conducted under real conditions (with 5 cars of different weights) in the range of inclination of entry of $2-4^{\circ}$ also showed a sufficient inclination of $2^{\circ}$.

Drum rotation of the model is driven by a gear with a toothed belt and an electronic option to change the rotation speed.

The drum rotation is forced by the drive unit, the motor of which, through the flexibly mounted "Nord" reducer, drives the chain gear, whose pin chain is multi-point-mounted to the external frame of the drum. The total drive ratio is $i=2550$, which gives the drum speed $n=0.57 \mathrm{rpm}$.

In addition, the inclusion of a frequency inverter in cooperation with the electric motor makes it possible to slow down or speed up the drum rotation.

The analysis of the reduction model and, in particular, the reliability of the car's movement within the car park has created the need to solve the technical problems of blockades. The 
problem of blockades of the car entry and exit from the parking platform has also been solved structurally.

The reduction model made can be used in further stages of work, to simulate tests defining the performance parameters of the future prototype.

\section{Correlation of model parameter tests with computer tests - determining the durability and reliability of the model}

The PO10 rotary car park model reflecting the adopted function of parking cars according to the developed parking technologies allowed for the correlation of results obtained by computer with the results of model tests. The structure and construction of the car park model were fully possible. Computer-developed construction elements as well as static and kinematic systems allowed for the creation of elements, units and assembly of a model fulfilling operating conditions in accordance with the assumed functions.

Also, a full correlation was obtained between computer model tests in the scope of production, assembly and operation of the electronic part controlling the reduction model.

Model tests in combination with the reduction model made, extended the scope of these tests to examples of constructional and electronic solutions that can be used in the design and implementation of the prototype. The results of these works also fully correlate with model tests.

Computer model tests have created the possibility of design and implementation of a fully functional reduction model, the implementation of the idea of a new method for parking cars.

The durability and reliability of the reduction model were tested in a 200-hour operation of the model in $90 \%$ operation cycles with "full load". The number of "entries" and "exits" was variable, on average 9 per hour, 1800 during the test period.

In the mechanisms of blockades (thresholds), no damage was found during the testing period - proper opening and closing of thresholds.

Car models also moved freely on entry and parking channels in accordance with the direction of their inclination. However, during the tests, it was found that a more favourable shape of the "channels" would be a section of the circle instead of a rectangle (more favourable tyre position, lower rolling resistance).

Durability, wear of individual elements of the car park model was only possible within the scope of the structure made under the test conditions. Elements and units of the car park did not show measurable wear [5]. 


\section{Summary}

The problem of "parking cars" is a significant problem of road traffic. The direction of improvement in the problem of parking cars is to create places, ways to leave the car for a certain time, parking it safely. Correction of this problem is to be conducted in the tests on new, functionally efficient methods of parking cars. The offered "rotary car park" is such a solution.

The patent, literature, Internet researches and own experience confirmed the novelty, the originality of the parking method and associated "rotary car park" with parking technology. Computer modelling and tests have been conducted in the field of construction and automation of the car park operation. Modelling of the mechanical part confirmed the possibilities and pointed to specific solutions of the construction units. Similar results were obtained in the tests of automatic, electronic control of the "car park" operation. The adopted methodology and research programmes were correctly and effectively selected, which also allowed to obtain the right correlation between computer tests and designs of structural and electronic solutions. The results of these works significantly created the construction possibilities for the implementation of the "car park" prototype.

The analysis of the model and its tests pointed to the positive features of this solution for parking cars.

The created reduction model made designed, in further stages of work, to simulate tests defining the performance parameters of the future prototype.

An important task of the model is also to be its illustrative, promotional and advertising role. Such a developed model can be the basis for the development of a prototype.

\section{Conclusions}

The basic conclusion from the presented work is the advisability of its continuation in the scope of further tests on the presented parking method and its technology, as well as the development of the scope of work for the performance of full technical documentation, creating and testing a prototype, implementation into production.

For the planned further work on the "rotary car park", it is necessary to perform full structural, mechanical and automation calculations of the car park as well as to develop and prepare technical documentation. A separate task is to document the "underground" part of the car park, which is within the scope of construction tests. Making cost estimates: technical documentation with the "underground" part of the car park, making a prototype of the PO-10 or PO-20 car park.

The implementation of the aforementioned objectives would allow for the introduction of a new, original scientific achievement for use, resulting in an improvement of the increasing inconvenience of parking cars. 


\section{References}

[1] EN ISO 9001:2008 Quality management systems - Requirements.

[2] ISO 14000 Environmental management.

[3] ISO 14050:2009 Environmental management - Vocabulary.

[4] ISO 26800:2011, Ergonomics - General approach, principles and concepts.

[5] Stolarski B. et al., Modelowanie i optymalizacja obrotowego parkingu samochodowego, projekt badawczy [Modelling and optimisation of rotary parking system, research project], Politechnika Krakowska, Kraków 2011.

[6] Borek J., Mruk A., Stolarski B., Studium obrotowego parkingu samochodów [Study of a rotary car park], Mechanics and Mechanical Engineering, Vol. 9, No. 1/2005.

[7] https://www.youtube.com/watch?v=q3Kju88On7E (access: 7.11.2017).

[8] Borek J., Stolarski B., Wielopoziomowy, wolno stojacy, obrotowy parking samochodowy - studium [Multi-level, free-standing rotary car park - study], Unpublished work, Kraków 2005.

[9] Korzeniowski W., Parkingi i garaże dla samochodów osobowych [Car parks and garages for passenger cars], WC0113, Warszawa 2000.

[10] Kwaśniewski J., Programowalne sterowniki przemysłowe w systemie sterowania [Programmable industrial controllers in the control system], Author's edition, Kraków 1999.

[11] Urbanowicz H., Napęd elektryczny maszyn roboczych [Electric drive of working machines], WNT, Warszawa 1979.

[12] Miedziński B., Elektrotechnika. Podstawy i instalacje elektryczne. [Electrotechnology. Basics and electrical installations], PWN, Warszawa 2000.

[13] Przeździecki F., Elektrotechnika i elektronika [Electrical and Electronic Engineering], PWN, Warszawa 1982.

[14] Niderliński A., Systemy komputerowe automatyki przemysłowej [Computer systems for industrial automation], Vol. 2, WNT, Warszawa 1985.

[15] Wonderware, InTouch - Podręcznik użytkownika [User Guide], Kraków 1997.

[16] Stolarski B., Metody taksonomiczne w technologii samochodów [Taxonomic methods in car technology], Monograph No. 97, Politechnika Krakowska, Kraków 1990.

[17] Taguchi G., Introduction to Quality Engineering, Designing Quality into Products and Process, translation, Sekkei Sha, Tokio 1986.

[18] http://www.woehr.de/-internetowy (access: 7.11.2017).

[19] http://www.morski.com.pl/ - web portal of the Polish integrator of the Wöhr company (access: 7.11.2017).

[20] http://www.sels.com.pl/index2php (access: 7.11.2017).

[21] Kacznia J., Polański Ł., Diploma thesis.

[22] Skrzyniowski A., Modelling and optimization of rotary parking system, Scientific Conference on Automotive Vehicles and Combustion Engines, KONMOT, IOP Publishing, IOP Conf. Series: Materials Science and Engineering 148, 2016, 012051 doi:10.1088/1757899X/148/1/012051.

[23] Stańko K., Przegląd i charakterystyka systemów parkingowych [Overview and summary of parking systems, Mechanics], Czasopismo Techniczne 9-M/2012. 
[24] http://blog.immobile.com.pl/historia-rozwoju-automatycznych-systemow-parkowania-na-swiecie/ (access: 9.03.2017)

[25] http://dokk1-parkering.dk/en/plant.aspx (access: 20.03.2018).

[26] Borek J., Wielopoziomowy, wolnostojacy parking samochodowy (parking obrotowy) [MultiLevel Car Park (Rotary Car Park)], Zeszyty Naukowo-Techniczne Stowarzyszenia Inżynierów i Techników Komunikacji w Krakowie [Research and Technical Papers of Polish Association for Transportation Engineers in Cracow], Conference Materials, 2007. 